\title{
The Financing Constraints Hypothesis Controversy: Some Evidence For The Portuguese Manufacturing Sector
}

Jorge Cunha, University of Minho, Portugal

António Paisana, University of Minho, Portugal

\begin{abstract}
In the last two decades, an intense debate on the influence of financing constraints on the investment decisions of firms has emerged. One point of view (e.g. Fazzari, Hubbard and Petersen, 1988) argues that investment spending of a firm is affected by its level of internal funds. Another point of view (e.g. Kaplan and Zingales, 1997) argues that the investment-cash flow sensitivity cannot be used as a measure of financing constraints. Although, these two positions seem contradictory, this paper proposes a new test aiming at reconciling these two opposite views. This new test emphasizes the crucial role that the classification criteria used plays on the empirical results obtained. Therefore, two main empirical predictions were tested. Firstly, if firms are classified according to the degree of asymmetric information problems that they face in financial markets, a higher sensitivity of investment to cash flow would be expected for firms that face these problems at a higher level. Secondly, if firms are classified according to their financial status, investment by firms in a better financial position would be expected to be more sensitive to cash flow variations. The empirical findings obtained in this paper, using a sample of Portuguese manufacturing firms, did not allow to confirm these empirical predictions. In fact, from the regression results obtained, it was possible to see that the cash flow variable has a major impact for firms facing higher asymmetric information problems in financial markets and for firms in poor financial status. Thus, one can be led to think that these results would favour the predictions of Fazzari, Hubbard and Petersen (1988) instead of the one's proposed by Kaplan and Zingales (1997).
\end{abstract}

Keywords: Investment, financing constraints, asymmetric information, financial status, panel data

\section{INTRODUCTION}

$\mathrm{n}$ the last two decades, an intense debate emerged on whether investment decisions of firms are affected
by financing constraints.

Fazzari, Hubbard and Petersen (1988) argue that, at least for certain types of firms (e.g. small, young and low-dividend payout), investment spending is affected by the level of internal funds. Although some kind of firms can easily obtain external funds to smoothen their investment expenses when internal funds fluctuate, the time and the amount of capital outlays of other firms, with limited or no access to external funds, will likely be conditioned by fluctuations in internal funds. This situation of under-investment of firms is due to information problems in financial markets ${ }^{1}$. The findings of Fazzari, Hubbard and Petersen (1988) have been corroborated by a large body of empirical evidence ${ }^{2}$.

\footnotetext{
${ }^{1}$ See the works of Jensen and Meckling (1976) on agency theory, and the works of Stiglitz and Weiss (1981) and Myers and Majluf (1984) on asymmetric information problems.

${ }^{2}$ For example, United States [e.g. Whited (1992); Fazzari and Petersen (1993); Vogt (1994); Gilchrist and Himmelberg (1995); Chirinko and Schaller (1995); Hubbard, Kashyap and Whited (1995); Lamont (1997)], Canada [e.g. Schaller (1993)], Mexico [e.g. Gelos and Werner (2002)], Germany [e.g. Mizen and Vermeulen (2005)], United Kingdom [e.g. Bond and Meghir (1994);
} 
Kaplan and Zingales (1997), on the other hand, argue that the investment-cash flow sensitivity cannot be used as a measure of financing constraints. In fact, Kaplan and Zingales (1997) found that investment by financially healthy firms was more sensitive to fluctuations in cash flows. A similar finding was attained by Cleary (1999) and Kadapakkam, Kumar and Riddick (1998).

In this context, the present paper aims at contributing to the empirical literature on the investment-cash flow relationship by presenting a new test for measuring the impact of financial variables on the investment spending of firms. This new test, based on data from a sample of Portuguese manufacturing firms, emphasizes the crucial role that the classification criteria used plays on the empirical results obtained. Two main empirical predictions were tested. Firstly, if firms are classified according to the degree of asymmetric information problems that they face in financial markets, a higher sensitivity of investment to cash flow would be expected for firms that face these problems at a higher level. Secondly, if firms are classified according to their financial status, investment by firms in a better financial position would be expected to be more sensitive to cash flow variations.

The remainder of the paper is organised as follows. Section 2 presents a brief overview of the literature on the investment-cash flow relationship. Section 3 provides a brief description of the data set and the classification criteria used. Section 4 describes the specification adopted for the econometric investment equation. Section 5 presents the estimation results obtained. Finally, section 6 presents the main conclusions of the tests undertaken.

\section{LITERATURE REVIEW}

Given the controversy generated by the opposite findings of Fazzari, Hubbard and Petersen (1988) and Kaplan and Zingales (1997), a number of authors have proposed several explanations in an attempt to reconcile those findings.

One line of research, followed by Allayannis and Mozumdar (2004), explained these two apparently opposite results, by emphasising the impact that the negative cash flows have on regression results. These authors highlighted the impact that a bad financial situation of a firm has on investment. In fact, in these cases, investment expenses could not react to changes in cash flows and a severe lack of funds can lead to situations of financial distress, where a firm can only make the absolute essential investments. Therefore, it is impossible to have more cuts in investment in response to a decline in cash flows, hence the sensitivity investment-cash flow is very low (or inexistent). Allayannis and Mozumdar (2004) argued that the more constrained firms have more restricted access to external financing, thereby reaching more rapidly this "minimal investment stage". As a result, an unconstrained firm is likely to have a higher investment-cash flow sensitivity than a constrained one, when internal funds are particularly low. To identify firms in financial distress, Allayannis and Mozumdar (2004) suggested that negative cash flows could be a good proxy. If, in the group of firms classified as more financially constrained, a large fraction of firms with negative cash flows is included, then the existence of low investment-cash flow sensitivity can be explained.

Another line of research followed by several authors consisted in investigating whether there is a U-shaped relationship between investment and internal funds.

Cleary, Povel and Raith (2007) developed a static model that attempts to explain the relationship between the level of investment spending of a firm and its level of internal funds. Their model is based on following three main assumptions: a) external funds are more costly than internal funds; b) the cost of raising funds is endogenously determined; and c) a firm can choose between larger and smaller investments. The main finding of Cleary, Povel and Raith (2007: 1) is that "a firm's investment is a U-shaped function of its internal funds". This result is due to the fact that there are two opposing effects that occur simultaneously: a cost effect and a revenue effect. The cost effect means that investment tends to decrease when internal funds decline, due to the increase in the cost of external

Goergen and Renneboog (2001)], France [e.g. Bond, Elston, Mairesse and Mulkay (2003)], Italy [e.g. Vermeulen (2002)], Spain [e.g. Palenzuela and Iturriaga (1998)], Belgium [e.g. Deloof (1998)], Czech Republic [e.g. Bo, Lensink and Sterken (2003)], Japan [e.g. Hoshi, Kashyap and Scharfstein (1991)], South Korea [e.g. Shin and Park (1999); Kim (1999)], Australia [e.g. Mills, Morling and Tease (1995)]. 
funds. The revenue effect derives from the fact that when a firm makes an investment, this is likely to increase its revenues in the future, thus allowing to pay their debts. Therefore, if the former effect dominates, an increase in internal funds leads to an increase in investment spending. On the other hand, if the latter effect dominates, an increase in internal funds leads to a decrease in investment spending.

Kasahara (2008) developed a dynamic model of investment where he demonstrated that the possibility of a severely constrained firm to invest more than a less constrained one. The model is based in two important assumptions: (a) the project value and the degree of financing constraints can vary over time; and (b) there is an irreversibility of investment decisions. In his analysis, Kasahara (2008) identifies two effects: the cost effect (meaning that external funds become more costly when there is a decline in internal funds, due to an increase in financial risk) and the "risk-preemptive" effect (meaning that firms can have an incentive to increase their investment expenses to avoid further financial risk in a future period, regardless of an increase in the cost of funds in the present). The conclusion that a more constrained firm invest more that an unconstrained one is reached when the "risk-preemptive effect" overweights the cost effect.

Lyandres (2007) highlighted the importance of the "model set-up" in understanding the investmentfinancing constraints relationship. In fact, Lyandres (2007) argues that, in the context of a static model (where it is assume that the investment decision is a "now or never" decision), it is plausible to reach the conclusion that there is a monotonic relation between investment decisions and the degree of financing constraints. However, when considering a dynamic model (where it is assumed that the investment decision is of the type "now or maybe later"), that relationship can be non-monotonic. In the dynamic setting proposed by Lyandres (2007), two opposite effects counterbalance each other: the "static effect" and the "dynamic effect". An increase in the cost of external financing leads, through the "static effect", to a decline in the attractiveness of the current investment. But it is also reflected in a decline in the attractiveness of the future investment, through the "dynamic effect". Lyandres (2007) argues that the "static effect" dominates the "dynamic effect" for firms relatively more constrained that face higher costs of external funds. However, the "dynamic effect" dominates the "static effect" for firms relatively not so constrained. This results in a "U-shaped" relationship between the cost of external financing and the sensitivity of investment to internal funds.

Boyle and Guthrie (2003) presented a dynamic model in which the optimal timing for an investment decision assumes a critical role. In the development of their model, these authors identified two opposite effects that offset each other: a cost effect and a "wait-risk" effect. The former means that more funds lead to a decrease in the cost of investment and to an increase in investment. The latter means that more funds decrease the risk of waiting to invest, therefore increasing the opportunity cost of current investment, which leads to a decrease in investment. Therefore, according to Boyle and Guthrie (2003), two situations can happen: (a) a situation of underinvestment (resulting from the cost effect); and (b) a situation of accelerated investment (resulting from the "risk of wait" effect). If this second effect prevails in certain types of firms (which is more likely in the case of high liquid firms), it would be expected a larger sensitivity of investment to cash flows for this kind of firms.

However, Almeida and Campello (2006) proposed yet another type of explanation for the controversy in the results obtained for the investment-cash flow relationship. In fact, these authors developed a theoretical argument which allows them to identify whether financing imperfections affect the investment behaviour of firms. A key element in this approach is the degree of "asset tangibility" of the assets that a firm owns. That is, the larger the fraction of the firms' assets that can be given as collateral, the more borrowed funds a firm can use to finance their investment plans. Therefore, Almeida and Campello (2006) were able to demonstrate that, in the case of constrained firms, the investment-cash flow relationship is monotonic, since there is a low degree of "asset tangibility". On the other hand, if there is a high degree of "asset tangibility" (which means that firms tend to be financially unconstrained), the link between investment and cash flow weakens, hence the assumption of monotonicity is not verified.

Finally, Caggese (2007) suggested a new test for the financing constraints hypothesis. The proposed test is derived from a structural model of a risk-taking firm that produces output from two complementary inputs: variable and fixed capital. Caggese (2007) demonstrates that, in the presence of financing imperfections, the correlation between the financial status of a firm and the investment in variable capital is a good indicator of the presence of 
financing constraints. Caggese (2007) argues that this new test has the important advantage of reducing the misspecification and omitted variables problems in the investment equation, since variable capital investment is less affected by adjustment costs than fixed investment. Therefore, it is easier to distinguishing between the financial factor effects from the productivity shock effects on investment decisions of firms.

\section{DATA}

\section{Sample and Variables Used}

The data used in the empirical study was provided by the Bank of Portugal Central Balance-Sheet Department. This department gathers economic and financial information for a sample of non-financial corporations. As a common standard in the majority of studies concerning the investment-cash flow relationship, the data used relates to firms belonging to the manufacturing sector. The study covers a period between 1990 and 2000 .

In order to be included in the sample firms had to meet several criteria ${ }^{3}$. Firstly, only private firms, belonging to the manufacturing sector, with at least 25 employees, were considered. Secondly, only firms that presented values for all variables and for every year of the period considered were selected. Finally, firms with outlier values were eliminated. These resulted in a balanced panel data set comprising 714 firms.

As far as the variables used in the empirical study are concerned, they were computed from the accounting information of firms and comprised the following:

- $\quad$ Investment (I): corresponds to acquisitions of structures and equipments;

- $\quad$ Stock of capital (K): represented by fixed assets;

- $\quad$ Sales (S): are total turnover of the firm;

- $\quad$ Cash flow (CF) given by the sum of profits and depreciation.

- $\quad$ Debt (D) corresponds to the total interest-bearing liabilities of the firm.

\section{Criteria for Splitting Firms}

This subsection presents the criteria used to identify firms according to (1) the degree of asymmetric information problems in financial markets and (2) to its financial status.

\section{Proxies for asymmetric information}

To classify firms according to the degree of asymmetric information problems they face in financial markets, two criteria were used: size and age.

The first criterion used to classify firms was size (large firms vs. small firms). The hypothesis under test was whether the impact of cash flows is higher for small firms than for larger ones. Actually, some authors (e.g. Gelos and Werner, 2002, Chow and Fung, 2000, Kim, 1999, Schiantarelli, 1996, and Gilchrist and Himmelberg, 1995) argue that larger firms face fewer asymmetric information problems in financial markets, thus are less subject to financial restrictions. Several reasons may justify this argument. Firstly, larger firms have an easier access to capital markets, due to the possibility of using the firm's assets as collateral. Secondly, it is likely that transaction costs for new share or bond issues decrease according to size. Thirdly, larger companies can use more different sources of funding than small companies, which allow large companies to reduce the risk of financing. Finally, it is likely that small firms suffer more from the idiosyncratic risk.

\footnotetext{
${ }^{3}$ It should be noticed that the identification of each firm was not known to the authors in order to meet statistical confidentiality. Firms were, only, identified by a number.
} 
To identify the large and the small firms, the sales variable was used. A firm was included in the group of large firms if it had a sales value greater than $€ 4,570,000^{4}$. Otherwise, it was included in the group of small firms. Each group is constituted by 174 and 540 firms, respectively. Table 1 shows descriptive statistics for both types of firms - large and small.

Table 1 - Descriptive Statistics for Firms Classified According to Size (S.D. indicates Standard Deviation)

\begin{tabular}{|l|c|c|c|c|}
\hline \multirow{2}{*}{ Variables } & \multicolumn{2}{c|}{ Large Firms } & \multicolumn{2}{c|}{ Small Firms } \\
\cline { 2 - 5 } & Mean & S. D. & Mean & S. D. \\
\hline $\mathrm{K}(€)$ & $9,593,937$ & $10,156,390$ & $1,287,812$ & $1,605,958$ \\
\hline $\mathrm{I}(€)$ & $1,941,194$ & $2,898,260$ & 298,762 & 524,665 \\
\hline $\mathrm{I}_{\mathrm{t}} / \mathrm{K}_{\mathrm{t}-1}$ & 0.268 & 0.322 & 0.352 & 0.620 \\
\hline $\mathrm{S}_{\mathrm{t}} / \mathrm{K}_{\mathrm{t}-1}$ & 5.493 & 5.208 & 6.528 & 8.923 \\
\hline $\mathrm{CF} \mathrm{F}_{\mathrm{t}} / \mathrm{K}_{\mathrm{t}-1}$ & 0.356 & 0.380 & 0.368 & 0.683 \\
\hline $\mathrm{D}_{\mathrm{t}-1} / \mathrm{K}_{\mathrm{t}-1}$ & 0.772 & 0.990 & 0.613 & 1.385 \\
\hline
\end{tabular}

The main conclusions are the following. Firstly, the mean value of fixed assets and the mean value of investment in fixed assets are seven and six times greater for large firms than for small firms, respectively. This fact clearly shows how different the firms included in each group are. Secondly, the mean rate of investment in fixed assets is greater for small firms than for large firms (35\% vs. $27 \%$, respectively). Thirdly, during the period under study, the cash flow rates were similar for both types of firms. Finally, large firms rely more on debt than small firms. This fact may suggest that large firms have an easier access to financial markets than small firms, which is an indication that financing constraints might exist in financial markets.

The second criterion used to identify firms according to asymmetric information problems was a firm's age (mature firms vs. young firms). The hypothesis under test was whether the impact of cash flows is higher for young firms than for mature ones. Actually, some authors (e.g. Kim, 1999, Chirinko and Schaller, 1995, and Oliner and Rudebusch , 1992) argue that mature firms are less likely to face information problems in capital markets. Two main reasons justify this rationale. Firstly, creditors have, in general, more information about mature firms, since they have been visible for a longer period of time in the market. Secondly, mature firms can establish continued relationships with creditors and suppliers based on mutual confidence, which helps alleviate information problems.

The cut-off value chosen for this criterion was the age of 10 years to avoid the group of young firms to be comprised of a small number, which could affect the quality of regression estimates. Therefore, the group of mature firms includes 548 firms and the group of young firms is comprised of 166 firms. Table 2 shows descriptive statistics for both types of firms - mature and young.

Table 2 - Descriptive Statistics for Firms Classified According to Age (S.D. indicates Standard Deviation)

\begin{tabular}{|l|c|c|c|c|}
\hline \multirow{2}{*}{ Variables } & \multicolumn{2}{c|}{ Mature Firms } & \multicolumn{2}{c|}{ Young firms } \\
\cline { 2 - 5 } & Mean & S. D. & Mean & S. D. \\
\hline $\mathrm{K}(€)$ & $3,730,392$ & $6,846,055$ & $1,930,775$ & $3,737,832$ \\
\hline $\mathrm{I}(€)$ & 780,090 & $1,814,817$ & 431,387 & 934,335 \\
\hline $\mathrm{I}_{\mathrm{t}} / \mathrm{K}_{\mathrm{t}-1}$ & 0.319 & 0.523 & 0.370 & 0.666 \\
\hline $\mathrm{S}_{\mathrm{t}} / \mathrm{K}_{\mathrm{t}-1}$ & 6.066 & 7.404 & 6.968 & 10.333 \\
\hline $\mathrm{CF}_{\mathrm{t}} / \mathrm{K}_{\mathrm{t}-1}$ & 0.365 & 0.563 & 0.368 & 0.789 \\
\hline $\mathrm{D}_{\mathrm{t}-1} / \mathrm{K}_{\mathrm{t}-1}$ & 0.671 & 1.424 & 0.590 & 0.769 \\
\hline
\end{tabular}

\footnotetext{
${ }^{4}$ This cut-off value corresponds to the mean value between the mean value of sales for the manufacturing sector in 1990 and in 2000, respectively (the first and the last year of the sample), as they appear in the Sector Tables produced by the Central Balancesheet data Office of the Bank of Portugal.
} 
As can be observed from the table, mature firms present mean values for fixed assets and for investment in fixed assets that are twice as large as that for young firms. This is an indication that mature firms tend to be larger than young firms. However, this effect tends to be counterbalanced as young firms show a mean rate of investment in fixed assets higher than mature firms (37\% vs. $32 \%)$. Notice, also, that mature firms rely more on debt than young firms. This can be explained by the fact that mature firms are less subject to information problems in financial markets.

\section{Proxies for the financial status of a firm}

To classify firms according to its financial status two criteria were used: interest coverage ratio and the probability of bankruptcy.

The decision to split the sample according to the interest coverage ratio ${ }^{5}$ is justified by the fact that the interest coverage ratio can be thought of as a proxy for the premium that firms have to pay for external finance (Guariglia, 1999). Alternatively, the coverage ratio can be seen as an indicator of the level of internal funds that a firm possesses and which it can use to finance its investment projects. Therefore, it is assumed that financial variables have a greater impact on investment expenses of high interest coverage firms than on low interest coverage firms.

In the empirical study, a cut-off value of five was used to split firms. On the one hand, five corresponds to the mean value shown in the Sector Tables produced by the Central Balance-sheet data Office of the Bank of Portugal for the period under analysis. On the other hand, this value is of the same magnitude as the one used by Guariglia (1999: 46) for UK, which indicates that "a threshold of five represents the level at which bankers might begin to feel concern about the ability of a company in the manufacturing sector to service and/or pay back its debts". Therefore, the group of firms with high coverage ratio is comprised of 312 firms and the group of low coverage firms includes 402 . Table 3 shows descriptive statistics for both types of firms - high and low coverage firms, respectively.

Table 3 - Descriptive Statistics for Firms Classified According to the Interest Coverage Ratio (S.D. indicates Standard Deviation)

\begin{tabular}{|l|c|c|c|c|}
\hline \multirow{2}{*}{ Variables } & \multicolumn{2}{|c|}{ High Coverage Firms } & \multicolumn{2}{c|}{ Low Coverage Firms } \\
\cline { 2 - 5 } & Mean & S. D. & Mean & S. D. \\
\hline $\mathrm{K}(€)$ & $3,564,357$ & $6,849,782$ & $3,116,129$ & $5,847,064$ \\
\hline $\mathrm{I}(€)$ & 800,356 & $1,744,622$ & 620,368 & $1,585,138$ \\
\hline $\mathrm{I}_{\mathrm{t}} / \mathrm{K}_{\mathrm{t}-1}$ & 0.353 & 0.562 & 0.314 & 0.564 \\
\hline $\mathrm{S}_{\mathrm{t}} / \mathrm{K}_{\mathrm{t}-1}$ & 7.049 & 9.140 & 5.675 & 7.307 \\
\hline $\mathrm{CF}_{\mathrm{t}} / \mathrm{K}_{\mathrm{t}-1}$ & 0.489 & 0.709 & 0.269 & 0.527 \\
\hline $\mathrm{D}_{\mathrm{t}-1} / \mathrm{K}_{\mathrm{t}-1}$ & 0.410 & 1.057 & 0.840 & 1.436 \\
\hline
\end{tabular}

The main features are the following. Firstly, both types of firms tend to be of a similar size, since they have an almost identical mean value for the stock of fixed assets and investment in fixed assets. Secondly, high coverage firms have a cash flow rate double than that for low coverage firms. Finally, this type of firms relies heavily on debt to finance its operations.

The probability of bankruptcy was the last criterion used to classify firms. The motivation underlying the use of this criterion is based on Kaplan and Zingales (1997: 208): "It is plausible that financially distressed firms will exhibit low investment-cash flow sensitivities. For example, an insolvent firm might be forced by its creditors to use additional cash flow to repay debt rather than for capital expenditures. This necessarily will reduce the sensitivity of investment to cash flow".

\footnotetext{
${ }^{5}$ The interest coverage ratio is measured as the ratio between operating income and interest expenses.
} 
To measure the probability of bankruptcy, the Altman (1968) Z-Score was used. Hence, it is expected that internal funds (e.g. cash flows) have a major impact on capital expenditures of low probability of bankruptcy firms than for their counterparts. Each group of firms has exactly the same number ${ }^{6}-357$. Table 4 shows descriptive statistics for both types of firms - low probability and high probability firms.

Table 4 - Descriptive Statistics for Firms Classified According to the Probability of Bankruptcy (S.D. indicates Standard Deviation)

\begin{tabular}{|l|c|c|c|c|}
\hline \multirow{2}{*}{ Variables } & \multicolumn{2}{|c|}{ Low Probability Firms } & \multicolumn{2}{c|}{ High Probability Firms } \\
\cline { 2 - 5 } & Mean & S. D. & Mean & S. D. \\
\hline $\mathrm{K}(€)$ & $2,052,485$ & $4,758,290$ & $4,571,502$ & $7,333,920$ \\
\hline $\mathrm{I}(€)$ & 497,348 & $1,180,472$ & 900,690 & $2,007,605$ \\
\hline $\mathrm{I}_{\mathrm{t}} / \mathrm{K}_{\mathrm{t}-1}$ & 0.370 & 0.576 & 0.292 & 0.547 \\
\hline $\mathrm{S}_{\mathrm{t}} / \mathrm{K}_{\mathrm{t}-1}$ & 9.021 & 9.703 & 3.530 & 4.983 \\
\hline $\mathrm{CF}_{\mathrm{t}} / \mathrm{K}_{\mathrm{t}-1}$ & 0.497 & 0.696 & 0.233 & 0.506 \\
\hline $\mathrm{D}_{\mathrm{t}-1} / \mathrm{K}_{\mathrm{t}-1}$ & 0.602 & 1.227 & 0.702 & 1.371 \\
\hline
\end{tabular}

In comparison with high probability bankruptcy firms, low probability firms tend: (a) to be of smaller size; (b) to have a higher turnover of fixed assets; (c) to generate more cash flows as a proportion of fixed assets; and (d) to rely less on debt. Clearly, these features indicate that low probability of bankruptcy firms are in a better financial position than high probability of bankruptcy firms.

\section{ECONOMETRIC INVESTMENT EQUATION}

To test the two empirical predictions set forth in the introduction, two alternative specifications for the econometric investment equation were adopted: (a) an error-correction model and (b) an Euler-equation model.

\section{Error-Correction Model}

The error-correction model adopted in this paper follows the one proposed by Bond et al. (2003). According to these authors «the basic idea is to nest a long-run specification for the firm's demand for capital within a regression model that allows a flexible specification for shot-run investment dynamics to be estimated from the data». Therefore, the investment equation would be as follows:

$\mathrm{I}_{\mathrm{it}} / \mathrm{K}_{\mathrm{it}-1}=\rho\left(\mathrm{I}_{\mathrm{it}-1} / \mathrm{K}_{\mathrm{it}-2}\right)+\beta_{1} \Delta \mathrm{s}_{\mathrm{it}}+\beta_{2} \Delta \mathrm{s}_{\mathrm{it}-1}+\beta_{3}\left(\mathrm{k}_{\mathrm{it}-2}-\mathrm{s}_{\mathrm{it}-2}\right)+\alpha_{\mathrm{i}}+\alpha_{\mathrm{t}}+\varepsilon_{\mathrm{it}}$

where I represents the firm's investment in fixed assets; K is the firm's stock of capital; s corresponds to the natural logarithm of sales; $\mathrm{k}$ is the natural logarithm of the stock of capital; $\left(\alpha_{\mathrm{i}}\right)$ corresponds to the firm effect, $\left(\alpha_{\mathrm{t}}\right)$ to the time effect and $\left(\varepsilon_{\mathrm{it}}\right)$ is the error term. The subscripts $i$ and $t$ correspond to firm and time, respectively.

In order to analyse the impact of internal funds on investment decisions of firms, Bond et al. (2003) suggested to add current and lagged cash flow (CF) to Equation 1. In this paper, the lagged debt (D) variable was also included. Hence, the investment equation becomes:

$\mathrm{I}_{\mathrm{it}} / \mathrm{K}_{\mathrm{it}-1}=\rho\left(\mathrm{I}_{\mathrm{it}-1} / \mathrm{K}_{\mathrm{it}-2}\right)+\beta_{1} \Delta \mathrm{s}_{\mathrm{it}}+\beta_{2} \Delta \mathrm{s}_{\mathrm{it}-1}+\beta_{3}\left(\mathrm{k}_{\mathrm{it}-2}-\mathrm{s}_{\mathrm{it}-2}\right)+\beta_{4}\left(\mathrm{CF}_{\mathrm{it}} / \mathrm{K}_{\mathrm{it}-1}\right)+\beta_{5}\left(\mathrm{CF}_{\mathrm{it}-1} / \mathrm{K}_{\mathrm{it}-2}\right)+\beta_{6}\left(\mathrm{D}_{\mathrm{it}-1} / \mathrm{K}_{\mathrm{it}-1}\right)+\alpha_{\mathrm{i}}+\alpha_{\mathrm{t}}+\varepsilon_{\mathrm{it}}$

As far as the expected relationship between the dependent variable and the explanatory variables is concerned, it can be said that a positive relationship between the following variables would be expected:

\footnotetext{
${ }^{6}$ The decision of splitting the sample into two sub-samples with the same number of firms is due to the fact that no benchmark value for the Z-Score was found adequate to set as a threshold.
} 
1. $\quad$ investment (I) and sales growth (s), given the accelerator principle.

2. investment (I) and cash flow (CF). However, it is expected a differentiated impact (in terms of magnitude) of cash flow on investment expenses of firms, depending on the classification criteria adopted, as explained in the empirical predictions that are under testing.

On the other hand, a negative relationship would be expected:

1. between firms' investment (I) and the error-correction term $\left(\mathrm{k}_{\mathrm{it}-2}-\mathrm{s}_{\mathrm{it}-2}\right)$. In fact, when the capital stock is above its desired level, it is expected a lower investment in the future.

2. between firms' investment (I) and its debt level (D). This can be explained by the fact that the greater the debt the greater the proportion of operating earnings devoted to service debt, and less funds are left for investment.

\section{Euler-Equation Approach}

Another specification adopted for the econometric investment equation was based on the Euler approach. This approach derives from a structural model, in which it is possible to obtain, from the first-order conditions for a dynamic optimisation problem and assuming quadratic adjustment costs, the Euler equation for investment.

According to Gilchrist and Himmelberg (1995), the objective is to test whether an Euler equation derived under the assumption of perfect capital markets is rejected by the data. If, in fact, these markets are not perfect, the model would be misspecified for the group of firms more financially constrained. Moreover, the Euler equation approach takes into account explicitly the recurrent nature of a firm's decisions and reduces the information conditions to those necessary to determine the optimal course of investment, using the information available in each period (Palenzuela and Iturriaga, 1998). On other words, it is emphasized that the investment rate of period $t$ is positively related with the investment rate expected for the period $t+l$ (Bond and Meghir, 1994). Additionally, this approach has the advantage that the structure of the Euler equation model allows to control for the influence of financial variables on expectations of future profitability (Bond et al., 2003). (1994):

The empirical specification adopted for the econometric investment equation is based on Bond and Meghir

$$
(\mathrm{I} / \mathrm{K})_{\mathrm{it}}=\beta_{1}(\mathrm{I} / \mathrm{K})_{\mathrm{it}-1}+\beta_{2}(\mathrm{I} / \mathrm{K})^{2}{ }_{\mathrm{it}-1}+\beta_{3}(\mathrm{CF} / \mathrm{K})_{\mathrm{it}-1}+\beta_{4}(\mathrm{~S} / \mathrm{K})_{\mathrm{it}-1}+\beta_{5}(\mathrm{D} / \mathrm{K})^{2}{ }_{\mathrm{it}-1}+\alpha_{\mathrm{i}}+\alpha_{\mathrm{t}}+\varepsilon_{\mathrm{it}}
$$

where I represents the firm's investment in fixed assets; CF is cash flow; S corresponds to sales; and D is debt of the firm. All variables are divided by the stock of capital $(\mathrm{K})$ to address the problem of heteroscedasticity. $\left(\alpha_{\mathrm{i}}\right)$ corresponds to the firm effect, $\left(\alpha_{t}\right)$ to the time effect and $\left(\varepsilon_{\mathrm{it}}\right)$ is the error term. The subscripts $i$ and $t$ correspond to firm and time, respectively.

According to Bond and Meghir (1994), under the null hypothesis of no financial constraints, it would be expected the following signs for the parameters estimates: $\beta_{1}>1 ; \beta_{2}<0$ but $>1$ in absolute value; $\beta_{3}<0 ; \beta_{4}>0$; and $\beta_{5}>0$. Under the alternative hypothesis, investment spending is positively related to cash flows through the effect of financing constraints, suggesting that the Euler equation is misspecified (Bond et al, 2003).

\section{EMPIRICAL RESULTS}

In this section, the empirical results obtained for the investment-cash flow relationship are shown, for both specifications adopted for the econometric investment equation. When analysing regression results the main focus of attention is the estimated coefficient of the cash flow variable, which reflects the impact of internal funds on the capital expenditures of firms.

Given the possible endogeneity of the regressors that may occur as a result of the dynamic nature of the econometric specification, the Generalized Method of Moments (GMM) estimation procedure was adopted, as proposed by Arellano and Bond (1991). All equations were estimated in first differences to eliminate the firm- 
specific time-invariant effects. Lags of the dependent and explanatory variables were used as instruments.

\section{Error-Correction Model}

Firms Classified According to the Degree of Asymmetric Information Problems

Table 5 shows the regression results obtained when firms were classified according to the degree of asymmetric information problems they face (i.e. by size and age).

As seen in the table, internal funds have a major impact on investment expenses of firms that face more severe information problems in financial markets. In fact, for both small and young firms, the estimated coefficient on the cash flow variable is almost double that for large and mature firms. This finding gives support to the hypothesis of the existence of financing constraints on financial markets (at least for certain types of firms).

Table 5 - Regression Results for Firms Classified According to the Degree of Asymmetric Information Problems

\begin{tabular}{|c|c|c|c|c|}
\hline \multirow{2}{*}{ Independent Variable } & \multicolumn{2}{|c|}{ Size } & \multicolumn{2}{|c|}{ Age } \\
\hline & Large & Small & Mature & Young \\
\hline $\mathrm{I}_{\mathrm{it}-1} / \mathrm{K}_{\mathrm{it}-2}$ & $\begin{array}{c}0.175^{*} \\
(0.0303)\end{array}$ & $\begin{array}{c}-0.010 \\
(0.0268)\end{array}$ & $\begin{array}{l}-0.267 * \\
(0.0242)\end{array}$ & $\begin{array}{c}0.108^{*} \\
(0.0281)\end{array}$ \\
\hline$\Delta \mathrm{s}_{\mathrm{it}}$ & $\begin{array}{c}-0.071 * * * \\
(0.0439)\end{array}$ & $\begin{array}{c}0.094 \\
(0.0663)\end{array}$ & $\begin{array}{c}0.229 * \\
(0.0506)\end{array}$ & $\begin{array}{l}-0.155^{*} \\
(0.0598)\end{array}$ \\
\hline$\Delta \mathrm{s}_{\mathrm{it}-1}$ & $\begin{array}{c}-0.020 \\
(0.0444)\end{array}$ & $\begin{array}{c}0.012 \\
(0.0442)\end{array}$ & $\begin{array}{c}0.098 * * * \\
(0.0520)\end{array}$ & $\begin{array}{c}0.063 \\
(0.0398)\end{array}$ \\
\hline$\left(\mathrm{k}_{\mathrm{it}-2}-\mathrm{s}_{\mathrm{it}-2}\right)$ & $\begin{array}{c}0.039 \\
(0.0416) \\
\end{array}$ & $\begin{array}{c}-0.097 * * \\
(0.0383) \\
\end{array}$ & $\begin{array}{c}-0.388^{*} \\
(0.0569) \\
\end{array}$ & $\begin{array}{l}-0.067 * * \\
(0.0337) \\
\end{array}$ \\
\hline $\mathrm{CF}_{\mathrm{it}} / \mathrm{K}_{\mathrm{it}-1}$ & $\begin{array}{c}0.301^{*} \\
(0.0694)\end{array}$ & $\begin{array}{c}0.513^{*} \\
(0.0810) \\
\end{array}$ & $\begin{array}{c}0.323^{*} \\
(0.0189) \\
\end{array}$ & $\begin{array}{c}0.558^{*} \\
(0.0958) \\
\end{array}$ \\
\hline $\mathrm{CF}_{\mathrm{it}-1} / \mathrm{K}_{\mathrm{it}-2}$ & $\begin{array}{l}0.070 * * \\
(0.0291) \\
\end{array}$ & $\begin{array}{c}0.032 \\
(0.0467) \\
\end{array}$ & $\begin{array}{c}0.276^{*} \\
(0.0210) \\
\end{array}$ & $\begin{array}{l}-0.140 * * \\
(0.0612) \\
\end{array}$ \\
\hline $\mathrm{D}_{\mathrm{it}-1} / \mathrm{K}_{\mathrm{it}-1}$ & $\begin{array}{c}0.053^{*} \\
(0.0121)\end{array}$ & $\begin{array}{c}0.058 \\
(0.0376)\end{array}$ & $\begin{array}{l}0.068 * * \\
(0.0293)\end{array}$ & $\begin{array}{c}0.108^{*} \\
(0.0376)\end{array}$ \\
\hline Sargan test & 0.367 & 0.045 & 0.328 & 0.037 \\
\hline $\mathrm{N}^{\circ}$ Obs. & 1392 & 4320 & 4384 & 1328 \\
\hline
\end{tabular}

Dependent variable, $\mathrm{I}_{\mathrm{it}} / \mathrm{K}_{\mathrm{it}-1}$. The GMM first-differences estimation procedure was adopted. The instrument set used includes all right-side variables dated $t-2$. In the estimation time dummies were included. Standard errors are in parenthesis. *, **, and $* * *$ indicate significance at $1 \%, 5 \%$ and $10 \%$ level, respectively.

A surprising result is the negative sign in the variable sales growth (of the current period), which contradicts what one would be expecting, given de accelerator principle.

Finally, as expected, the coefficient on the error-correction term is negative (except for large firms where it is positive but has no statistical significance).

\section{Firms Classified According to the Financial Status}

Table 6 shows the regression results obtained when firms were classified according to their financial status (i.e. by the probability of bankruptcy and interest coverage ratio).

From the table, it is clear that internal funds have a higher influence on investment expenses of firms in a poor financial situation, contrary to what was expected. In fact, for this type of firm (high bankruptcy probability firms and low interest coverage ratio firms) the estimated coefficient on the cash flow variable is double that for healthier firms. Hence, this result does not corroborate the argument of Kaplan and Zingales (1997), suggesting that investment expenses of financially distressed firms could be insensitive to cash flow variations. 
Table 6 - Regression Results for Firms Classified According to its Financial Status

\begin{tabular}{|c|c|c|c|c|}
\hline \multirow{2}{*}{ Independent Variable } & \multicolumn{2}{|c|}{ Bankruptcy Probability } & \multicolumn{2}{|c|}{ Coverage Ratio } \\
\hline & High & Low & Low & High \\
\hline $\mathrm{I}_{\mathrm{it}-1} / \mathrm{K}_{\mathrm{it}-2}$ & $\begin{array}{c}0.113^{*} \\
(0.0262)\end{array}$ & $\begin{array}{c}-0.136^{*} \\
(0.0269)\end{array}$ & $\begin{array}{c}0.068 * \\
(0.0261)\end{array}$ & $\begin{array}{c}-0.120 * \\
(0.0268)\end{array}$ \\
\hline$\Delta \mathrm{s}_{\mathrm{it}}$ & $\begin{array}{l}-0.136^{* *} \\
(0.0543)\end{array}$ & $\begin{array}{c}0.016 \\
(0.0527)\end{array}$ & $\begin{array}{l}-0.110 * * \\
(0.0584)\end{array}$ & $\begin{array}{c}0.052 \\
(0.0521)\end{array}$ \\
\hline$\Delta \mathrm{s}_{\mathrm{it}-1}$ & $\begin{array}{c}0.081 \text { **** } \\
(0.0426)\end{array}$ & $\begin{array}{c}-0.003 \\
(0.0517)\end{array}$ & $\begin{array}{l}0.099 * * \\
(0.0423)\end{array}$ & $\begin{array}{c}0.047 \\
(0.0554)\end{array}$ \\
\hline$\left(\mathrm{k}_{\mathrm{it}-2}-\mathrm{s}_{\mathrm{it}-2}\right)$ & $\begin{array}{c}-0.097 * \\
(0.0320) \\
\end{array}$ & $\begin{array}{c}-0.103 * * \\
(0.0531) \\
\end{array}$ & $\begin{array}{c}-0.069 * * \\
(0.0332) \\
\end{array}$ & $\begin{array}{c}-0.173 * \\
(0.0494) \\
\end{array}$ \\
\hline $\mathrm{CF}_{\mathrm{it}} / \mathrm{K}_{\mathrm{it}-1}$ & $\begin{array}{c}0.671 * \\
(0.1132)\end{array}$ & $\begin{array}{c}0.352 * \\
(0.0291)\end{array}$ & $\begin{array}{c}0.665^{*} \\
(0.1196)\end{array}$ & $\begin{array}{c}0.335^{*} \\
(0.0237)\end{array}$ \\
\hline $\mathrm{CF}_{\mathrm{it}-1} / \mathrm{K}_{\mathrm{it}-2}$ & $\begin{array}{l}-0.204 * \\
(0.0585)\end{array}$ & $\begin{array}{c}0.183 * \\
(0.0293)\end{array}$ & $\begin{array}{l}-0.136 * * \\
(0.0610)\end{array}$ & $\begin{array}{c}0.173 * \\
(0.0313)\end{array}$ \\
\hline $\mathrm{D}_{\mathrm{it}-1} / \mathrm{K}_{\mathrm{it}-1}$ & $\begin{array}{c}0.152 * \\
(0.0318)\end{array}$ & $\begin{array}{c}0.005 \\
(0.0144)\end{array}$ & $\begin{array}{c}0.097 * \\
(0.0326)\end{array}$ & $\begin{array}{c}-0.026^{*} \\
(0.0085)\end{array}$ \\
\hline Sargan test & 0.098 & 0.056 & 0.382 & 0.0009 \\
\hline $\mathrm{N}^{\mathrm{o}}$ Obs. & 2856 & 2856 & 3216 & 2496 \\
\hline
\end{tabular}

Dependent variable, $\mathrm{I}_{\mathrm{it}} / \mathrm{K}_{\mathrm{it}-1}$. The GMM first-differences estimation procedure was adopted. The instrument set used includes all right-side variables dated $t-2$. In the estimation time dummies were included. Standard errors are in parenthesis. *, **, and $* * *$ indicate significance at $1 \%, 5 \%$, and $10 \%$ level, respectively.

However, it should, also, be noted that the coefficient of lagged cash flow is negatively signed for firms in poor financial situation, making the overall impact of cash flow variable on investment decisions of firms less markedly different between both types of firms.

An interesting finding is that the coefficients on the sales growth variables (of the current period) are correctly signed but are not statistically different from zero for healthier firms, whereas the opposite situation occurs for firms in bad financial position.

\section{Euler-Equation Approach}

Firms Classified According to the Degree of Asymmetric Information Problems

Table 7 shows the regression results obtained when firms were classified according to the degree of asymmetric information problems they face (i.e. by size and age).

Table 7 - Regression Results for Firms Classified According to the Degree of Asymmetric Information Problems

\begin{tabular}{|l|c|c|c|c|}
\hline \multirow{2}{*}{ Independent Variable } & \multicolumn{2}{|c|}{ Size } & \multicolumn{2}{c|}{ Age } \\
\cline { 2 - 5 } & Large & Small & Mature & Young \\
\hline$(\mathrm{I} / \mathrm{K})_{\mathrm{it}-1}$ & $2.014^{*}$ & $1.596^{*}$ & $2.139^{*}$ & $1.438^{*}$ \\
& $(0.1250)$ & $(0.1804)$ & $(0.1584)$ & $-1.743^{*}$ \\
\hline$(\mathrm{I} / \mathrm{K})^{2}{ }_{\mathrm{it}-1}$ & $-2.712^{*}$ & $-1.863^{*}$ & $-2.562^{*}$ & $(0.3016)$ \\
\hline$(\mathrm{CF} / \mathrm{K})_{\mathrm{it}-1}$ & $(0.1702)$ & $(0.2376)$ & -0.002 & $0.044^{*}$ \\
& 0.027 & $0.034^{*}$ & $(0.0134)$ & $(0.0104)$ \\
\hline$(\mathrm{S} / \mathrm{K})_{\mathrm{it}-1}$ & $(0.0201)$ & $(0.0072)$ & $0.015^{*}$ & $0.019^{*}$ \\
& $0.018^{*}$ & $0.019^{*}$ & $(0.0028)$ & $(0.0019)$ \\
\hline$(\mathrm{D} / \mathrm{K})^{2}{ }_{\mathrm{it}-1}$ & $(0.0033)$ & $(0.0019)$ & $0.017^{*}$ & $-0.002^{* *}$ \\
& 0.001 & $-0.002^{* *}$ & $(0.0055)$ & $(0.0007)$ \\
\hline Sargan test & $(0.0011)$ & $(0.0008)$ & 0.000014 & 0.0002 \\
\hline $\mathrm{N}^{\circ}$ Obs. & 0.005 & 0.000008 & 4932 & 1494 \\
\hline
\end{tabular}

Dependent variable, $(\mathrm{I} / \mathrm{K})_{\mathrm{it}}$. The GMM first-differences estimation procedure was adopted. The instrument set used includes all right-side variables dated $t-2$. In the estimation time dummies were included. Standard errors are in parenthesis. *, and $* *$ indicate significance at $1 \%$, and $5 \%$ level, respectively. 
In absence of financing constraints, the parameter of the cash flow variable should be negative and the parameter of the debt variable should be positive. However, this does not happen for firms a priori identified as more financially constrained (small and young firms). Therefore, the results in the table seem to indicate that firms facing higher information problems in financial markets are more dependent on internal funds than their counterparts. In fact, the value of the estimated parameter of the cash flow variable is higher and only has statistical significance for that type of firms.

\section{Firms Classified According to the Financial Status}

Table 8 shows the regression results obtained when firms were classified according to their financial status (i.e. by the probability of bankruptcy and interest coverage ratio).

Table 8 - Regression Results for Firms Classified According to its Financial Status

\begin{tabular}{|c|c|c|c|c|}
\hline \multirow{2}{*}{ Independent Variable } & \multicolumn{2}{|c|}{ Bankruptcy Probability } & \multicolumn{2}{|c|}{ Coverage Ratio } \\
\hline & High & Low & Low & High \\
\hline$(\mathrm{I} / \mathrm{K})_{\mathrm{it}-1}$ & $\begin{array}{c}1.239^{*} \\
(0.2134)\end{array}$ & $\begin{array}{c}2.750^{*} \\
(0.1664)\end{array}$ & $\begin{array}{c}1.245^{*} \\
(0.1829)\end{array}$ & $\begin{array}{c}2.648 * \\
(0.1474)\end{array}$ \\
\hline$(\mathrm{I} / \mathrm{K})^{2}{ }_{\mathrm{it}-1}$ & $\begin{array}{l}-1.436^{*} \\
(0.2929)\end{array}$ & $\begin{array}{l}-3.398^{*} \\
(0.2023)\end{array}$ & $\begin{array}{l}-1.453^{*} \\
(0.2436)\end{array}$ & $\begin{array}{l}-3.307^{*} \\
(0.1930)\end{array}$ \\
\hline$(\mathrm{CF} / \mathrm{K})_{\mathrm{it}-1}$ & $\begin{array}{c}0.046^{*} \\
(0.0123)\end{array}$ & $\begin{array}{c}0.003 \\
(0.0103) \\
\end{array}$ & $\begin{array}{c}0.040^{*} \\
(0.0119)\end{array}$ & $\begin{array}{c}0.004 \\
(0.0105) \\
\end{array}$ \\
\hline$(\mathrm{S} / \mathrm{K})_{\mathrm{it}-1}$ & $\begin{array}{c}0.024 * \\
(0.0040)\end{array}$ & $\begin{array}{c}0.014 * \\
(0.0019)\end{array}$ & $\begin{array}{c}0.020^{*} \\
(0.0023)\end{array}$ & $\begin{array}{c}0.012^{*} \\
(0.0020)\end{array}$ \\
\hline$(\mathrm{D} / \mathrm{K})^{2}{ }_{\mathrm{it}-1}$ & $\begin{array}{l}-0.002 * * \\
(0.0011)\end{array}$ & $\begin{array}{c}-0.001 \\
(0.0007)\end{array}$ & $\begin{array}{c}-0.001 * * * \\
(0.0007)\end{array}$ & $\begin{array}{l}-0.005^{*} \\
(0.0012)\end{array}$ \\
\hline Sargan test & 0.0006 & 0.000005 & 0.00006 & 0.000001 \\
\hline $\mathrm{N}^{\circ}$ Obs. & 3213 & 3213 & 3618 & 2808 \\
\hline
\end{tabular}

Dependent variable, $(\mathrm{I} / \mathrm{K})_{\mathrm{it}}$. The GMM first-differences estimation procedure was adopted. The instrument set used includes all right-side variables dated $t$ - 2 . In the estimation time dummies were included. Standard errors are in parenthesis. $*$, and $* * *$ indicate significance at $1 \%$, and $10 \%$ level, respectively.

Once again, cash flow has a major impact on investment of firms in poor financial situation, as it has been observed in Table 6, which contradicts the prediction of Kaplan and Zingales (1997). For firms in better financial position, the estimated coefficient of the cash flow variable is not statistically different from zero.

\section{Discussion of the Results}

From the regression results obtained above, it is clear that internal funds have a major impact for both firms facing higher asymmetric information problems in financial markets and firms in poor financial status. Therefore, these results seem to lend support to the predictions of Fazzari, Hubbard and Petersen (1988) instead of the one's proposed by Kaplan and Zingales (1997).

A different finding was obtained by Cleary (2006). This author, using a sample of firms from seven different countries, concludes that (a) «firms with stronger financial positions are more investment-cash flow sensitive than firms with weaker financial positions even after controlling for size and dividend payout»; (b) «higher payout firms are more investment-cash flow sensitive than lower payout firms even after controlling for size and financial strength» and «the impact of firm [...] is much weaker once financial health and dividend payout behaviour is controlled for. An explanation, proposed by Cleary (2006), for these results is the effect of the volatility of cash flows. In fact, Cleary (2006) found that firms possessing high volatility of cash flow have lower investmentcash flow sensitivities. Therefore, argues that «this may account for the contradictory empirical findings found in the literature if this volatility effect dominates other effects such as information asymmetry and agency costs that researchers attempt to measure using their financial constraint groupings». 
On the other hand, there are several empirical studies that corroborate the influence of internal funds on a firm's investment decision. For example, Agca and Mozumdar (2008) found that «the sensitivity of investment to the availability of internal funds is significant trough different time periods» and «is linked to capital market imperfections». In their empirical study they concluded that the «investment-cash flow sensitivity decreases when there is a reduction in capital market imperfections through increased fund flows, institutional ownership, analyst following, antitakeover amendments and with the existence of a bond rating». Therefore, they argue that «capital market factors that decrease market imperfections and as a result reduce the cost wedge between external and internal funds, lead to lower investment-cash flow sensitivities».

Islam and Mozumdar (2007), using a sample of firms from thirty one countries, examined whether the investment-cash flow sensitivity was affected by the degree of financial markets development. They concluded that «corporate investments are more sensitive to internal cash flow for firms in countries with less developed financial markets».

Moreover, Aggarwal and Zong (2006) studied the investment-cash flow relationship using a sample of firms from each of the two largest market- and bank-centered economies (US and UK vs. German and Japan). The findings obtained were (a) internal cash flows are significantly positively related to investment levels in all four countries, fact that they interpret as «strong evidence that firms have limited access to external finance and these results are consistent with the pecking order theory of corporate financing»; (b) «there is much support for the original FHP (1988) position in three of the four countries (UK, Germany, and Japan)» given that «investment levels in the financially stronger firms are less influenced by the availability of internal cash flows as such firms can presumably raise any necessary external funds for good projects».

Finally, Bhagat, Moyen and Suh (2005) compared the investment policy of distresses firms in relation to that of healthy firms. They obtain the following findings. Firstly, they document «a negative cash flow sensitivity for distressed firms with operating losses and a positive sensitivity for all other firms». Secondly, they show that «the negative cash flow sensitivity is generated by distressed firms with operating losses that invest more than the previous year. These firms invest more when their cash flows are decreasing. Because the investment is funded by equity claimants, the evidence suggests a gamble for resurrection». Thirdly, they provide evidence consistent with «an asset substitution problem only for the subset of financially distressed firms with operating losses that invest more than the previous year». Finally, they document that «healthy firms invest more and have a lower leverage than financially distressed firms».

\section{CONCLUSIONS}

Beginning with the paper of Fazzari, Hubbard and Petersen (1988), an extensive empirical literature has documented the influence of financial variables on investment decisions of firms, particularly for those facing higher information problems on financial markets, such as small and young firms. However, this empirical finding was questioned by Kaplan and Zingales (1997), who showed that the level of internal funds has a greater impact on investment expenses of financially healthier firms.

In this paper, we tried to shed some light in the investment-internal funds controversy by emphasising whether the classification criteria adopted to split firms into sub-samples has a major influence in the empirical results that have been obtained in different studies, which would allow to reconcile these results. In this sense, two main empirical predictions were tested. Firstly, if firms are classified according to the degree of asymmetric information problems that they face in financial markets, a higher sensitivity of investment to cash flow would be expected for firms that face these problems at a higher level. Secondly, if firms are classified according to their financial status, investment by firms in a better financial position would be expected to be more sensitive to cash flow variations.

However, the empirical findings obtained in this paper, using two different specifications for the econometric investment equation and a sample of Portuguese manufacturing firms, did not allow to confirm these empirical predictions. In fact, from the regression results obtained, it was possible to see that the cash flow variable has a major impact for both firms facing higher asymmetric information problems in financial markets and firms in 
poor financial status. Thus, one can be led to think that these results would favour the predictions of Fazzari, Hubbard and Petersen (1988) instead of the one's proposed by Kaplan and Zingales (1997). Yet, more research is needed to gain a consistent and unambiguous perception of the true relationship between a firm's investment expenses and its financial position.

In terms of policy implications, the strong connection between a firm's financial status and investment suggests that in the case, for example, of a restrictive monetary policy, the real economy will be affected not only through the traditional channel of the cost of capital, but also through the availability of funds channel, which means that an increase in interest expenses of firms will reduce the availability of relatively cheap internal funds and increase the cost of external funds. Another important policy implication resulting from this study is the impact of tax policy changes. The main argument is that when firms face restrictions in obtaining finance due to imperfections in the financial markets, any increase in the tax revenue coming from tax charged to firms has a negative impact on investment, since it limits the availability of funds to which the company can access to achieve its investment plans. Therefore, it could be argued that tax policy measures, such as the reduction in corporate tax rate, measures that disincentive high dividend payouts, accelerated depreciation allowances, and the introduction of an investment tax credit could induce more investment in fixed capital by firms.

\section{AUTHOR INFORMATION}

Jorge Cunha graduated in Economics in 1996 and has a Master's degree in Financial Economics, both attained at Coimbra University. He also holds a Ph.D degree in Engineering Economics (University of Minho). He is currently Assistant Professor at the University of Minho, where he teaches courses (both at graduate and post graduate levels) in Business Economics, Financial Engineering, Investment Appraisal, and Engineering Economics. His research interests include the study of the relationship between investment and finance decisions of firms, investment appraisal techniques, and economic impact studies.

António Paisana is an Economics graduate from Birmingham University (England, 1978) and holds a PhD degree in Transport from Loughborough University (England, 1992). He is an Associate Professor at Minho University and teaches graduate and post graduate degree courses on subjects of organizational and strategic management, leadership and economics engineering. The main research interests include cost and strategic management, the impact of public policies on the management of firms and regional studies.

\section{REFERENCES}

1. Agca, S., Mozumdar, A. (2008) 'The impact of capital market imperfections on investment-cash flow sensitivity', Journal of Banking and Finance, Vol 32, pp. 207-216.

2. Aggarwal, R., Zong, S. (2006) 'The cash flow-investment relationship: International evidence of limited access to external finance', Journal of Multinational Financial Management, Vol.16, pp. 89-114.

3. Allayannis, G., Mozumdar, A. (2004). 'The Impact of Negative Cash Flow and Influential Observations on Investment-Cash Flow Sensitivity Estimates', Journal of Banking and Finance, Vol. 28, pp. 901-930.

4. Almeida, H., Campello, M. (2006) 'Financial constraints, asset tangibility, and corporate investment', Working Paper 12087, NBER, Cambridge.

5. Altman, E. (1968). 'Financial Ratios, Discriminant Analysis and the Prediction of Corporate Bankruptcy', Journal of Finance, Vol. 23, pp. 589-609.

6. Arellano, M., Bond, S. (1991) 'Some tests of specification for panel data: Monte Carlo evidence and application to employment equations', Review of Economic Studies, Vol. 58, pp.277-297.

7. Bhagat,S., Moyen, N., Suh, I. (2005) 'Investment and internal funds of distressed firms', Journal of Corporate Finance, Vol. 11, pp. 449-472.

8. Bo, H; Lensink, R., Sterken, E. (2003). 'Uncertainty and Financing Constraints', European Finance Review, Vol. 7, pp. 297-321.

9. Bond, S., Elston, J., Mairesse, J., Mulkay, B. (2003). 'Financial Factors and Investment in Belgium, France, Germany, and the United Kingdom: A Comparison Using Company Panel Data', Review of Economics and Statistics, Vol. 85, pp. 153-65. 
10. Bond, S., Meghir, C. (1994). 'Dynamic Investment Models and the Firm's Financial Policy', Review of Economic Studies, Vol. 61, pp. 197-222.

11. Boyle, G.; Guthrie, G. (2003) 'Investment, uncertainty, and liquidity', Journal of Finance, Vol. 28, pp. 2143-2166.

12. Caggese, A. (2007) 'Testing financing constraints on firm investment using variable capital', Journal of Financial Economics, Vol. 86, pp. 683-723.

13. Chirinko, R., Schaller, H. (1995). 'Why Does Liquidity Matter in Investment Equations?', Journal of Money, Credit, Banking, Vol. 27, pp. 525-48.

14. Chow C, Fung M (2000): Small Businesses and Liquidity Constraints in Financing Business Investment: Evidence from Shangai's Manufacturing Sector. Journal of Business Venturing, Vol. 15, pp. 363-383

15. Cleary, S. (1999). 'The Relationship between Firm Investment and Financial Status', Journal of Finance, Vol. 54, pp. 673-92.

16. Cleary, S. (2006) 'International corporate investment and the relationships between financial constraint measures', Journal of Banking and Finance, Vol. 30, pp. 1559-1580.

17. Cleary, S., Povel, P., Raith, M. (2007). 'The U-Shaped Investment Curve: Theory and Evidence', Journal of Financial and Quantitative Analysis, Vol. 42, pp. 1-39.

18. Fazzari, S., Petersen, B. (1993). 'Working Capital and Fixed Investment: New Evidence on Financing Constraints', RAND Journal of Economics, Vol. 24, pp. 328-42.

19. Fazzari, S., Hubbard, R., Petersen, B. (1988). 'Financing Constraints and Corporate Investment', Brooking Papers on Economic Activity, Vol. 1, pp. 141-95.

20. Gelos, R., Werner, A. (2002). 'Financial Liberalization, Credit Constraints, and Collateral: Investment in the Mexican Manufacturing Sector', Journal of Development Economics, Vol. 67, pp. 1-27.

21. Gilchrist, S., Himmelberg, C. (1995). 'Evidence on the Role of Cash Flow for Investment', Journal of Monetary Economics, Vol. 36, pp. 541-72.

22. Goergen, M., Renneboog, L. (2001). 'Investment Policy, Internal Financing and Ownership Concentration in the UK', Journal of Corporate Finance, Vol. 7, pp. 257-84.

23. Guariglia, A. (1999). 'The effects of Financial Constraints on Inventory Investment: Evidence from a Panel of UK Firms', Economica, Vol. 66, pp. 43-62.

24. Hoshi, T., Kashyap, A., Scharfstein, D. (1991). 'Corporate Structure, Liquidity, and Investment: Evidence from Japanese Panel Data', Quarterly Journal of Economics, Vol. 106, pp. 33-60.

25. Hubbard, R. G. (1998) 'Capital market imperfections and investment', Journal of Economic Literature, Vol. 36, pp.193-227.

26. Hubbard, R., Kashyap, A., Whited, T. (1995). 'Internal Finance and Firm Investment', Journal of Money, Credit, Banking, Vol. 27, pp. 683-701.

27. Islam, S., Mozumdar, A. (2007) 'Financial market development and the importance of internal cash: Evidence from international data', Journal of Banking and Finance, Vol, 31, pp.641-658.

28. Jensen M., Meckling, W. (1976) 'The theory of the firm: Managerial behavior, agency costs and ownership structure', Journal of Financial Economics, Vol. 3, pp. 305-360.

29. Kadapakkam, P.; Kumar, P.; Riddick, L. (1998) 'The impact of cash flows and firm size on investment: The international evidence', Journal of Banking and Finance, Vol. 22, pp. 293-320.

30. Kaplan, S., Zingales, L. (1997). 'Do Investment-Cash Flow Sensitivities Provide Useful Measures of Financing Constraints?', Quarterly Journal of Economics, Vol. 112, pp. 169-215.

31. Kasahara, T. (2008) 'Severity of financing constraints and firms' investments', Review of Financial Economics, Vol. 17, pp. 112-129.

32. Kim, J. (1999). 'The Relaxation of Financing Constraints by the Initial Public Offering of Small Manufacturing Firms', Small Business Economics, Vol. 12, pp. 191-202.

33. Lamont, O. (1997). 'Cash Flow and Investment: Evidence from Internal Capital Markets', Journal of Finance, Vol. 52, pp. 83-109.

34. Lyandres, E. (2007) 'Costly external financing, investment timing, and investment-cash flow sensitivity', Journal of Corporate Finance, Vol. 13, pp. 959-980.

35. Mills, K., Morling, S., Tease, W. (1995). 'The Influence of Financial Factors on Corporate Investment', Australian Economic Review, pp. 50-64.

36. Mizen, P., Vermeulen, P. (2005). 'Corporate Investment and Cash-Flow Sensitivity: What Drives the Relationship?', ECB Working Paper Series 485. 
37. Myers, S., Majluf, N. (1984) 'Corporate financing and investment decisions when firms have information that investors do not have, Journal of Financial Economics, Vol. 13, pp. 187-221.

38. Oliner S, Rudebusch G (1992): Sources of the Financing Hierarchy for Business Investment and Agency Costs. Review of Economics and Statistics, Vol. 74, pp. 643-653.

39. Palenzuela, V., Iturriaga, F. (1998). 'Déterminants Financiers de l'Investissement en Capiatl Fixe: Le Cas Espagnol', Revue D'Economie Industrielle, pp. 25-48.

40. Schaller, H. (1993). 'Asymmetric Information, Liquidity Constraints and Canadian Investment', Canadian Journal of Economics, Vol. 26, pp. 552-74.

41. Schiantarelli F (1996): Financial Constraints and Investment: Methodological Issues and International Evidence. Oxford Review of Economic Policy, Vol. 12, pp. 70-89.

42. Shin, H., Park, Y. (1999). 'Financing Constraints and Internal Capital Markets: Evidence from Korean "Chaebols", Journal of Corporate Finance, Vol. 5, pp. 169-91.

43. Stiglitz J., Weiss, A. (1981) 'Credit rationing in markets with imperfect information', American Economic Review, Vol. 71, pp. 393-410.

44. Vermeulen, P. (2002). 'Business Fixed Investment: Evidence of a Financial Accelerator in Europe', Oxford Bulletin of Economic and Statistics, Vol. 64, pp. 213-31.

45. Vogt, S. (1994). 'The Cash Flow/Investment Relationship: Evidence from U.S. Manufacturing Firms', Financial Management, Vol. 23, pp. 3-20.

46. Whited, T. (1992). 'Debt, Liquidity Constraints, and Corporate Investment: Evidence from Panel Data', Journal of Finance, Vol. 47, pp. 1425-60. 
NOTES 